\title{
CXCR1 wt Allele
}

National Cancer Institute

\section{Source}

National Cancer Institute. CXCR1 wt Allele. NCI Thesaurus. Code C51371.

Human CXCR1 wild-type allele is located within 2q35 and is approximately $4 \mathrm{~kb}$ in length. This allele, which encodes C-X-C chemokine receptor type 1 protein, plays a role in proinflammatory cytokine activation, chemoattraction and activation of neutrophils and Gprotein activated second messenger signal transduction. 